\title{
Manganese Phthalocyanine as a Biomimetic Electrocatalyst for Phenols in the Development of an Amperometric Sensor
}

\author{
Wilney de Jesus R. Santos, ${ }^{a}$ Aline L. Sousa, ${ }^{a}$ Maria del Pilar T. Sotomayor, ${ }^{b}$ Flavio S. Damos,,${ }^{c e}$ \\ Sônia Maria C. N. Tanaka, ${ }^{a}$ Lauro T. Kubota ${ }^{d, e}$ and Auro A. Tanaka ${ }^{*, a, e}$
}

${ }^{a}$ Departamento de Química, Universidade Federal do Maranhão, 65085-580 São Luís-MA, Brazil

${ }^{b}$ Instituto de Química, Universidade Estadual Paulista, 14801-970 Araraquara-SP, Brazil

${ }^{c}$ Departamento de Química, Universidade Federal dos Vales do Jequitinhonha e Mucuri, 39100-000 Diamantina-MG, Brazil

'Instituto de Química, Universidade Estadual de Campinas, 13084-971 Campinas-SP, Brazil

eInstituto Nacional de Ciência e Tecnologia de Bioanalítica, 13083-970 Campinas-SP, Brazil

\begin{abstract}
A construção de um sensor amperométrico para compostos fenólicos usando um eletrodo de pasta de carbono modificado com ftalocianina de manganês e histidina é relatado. Sob condições otimizadas, em $0 \mathrm{mV} v s \mathrm{Ag} / \mathrm{AgCl}$ numa solução tampão fosfato $0,1 \mathrm{~mol} \mathrm{dm}^{-3}(\mathrm{pH} 7,0)$ contendo $\mathrm{H}_{2} \mathrm{O}_{2} 250 \mu \mathrm{mol} \mathrm{dm}{ }^{-3}$, uma resposta linear para catecol entre 20 e $130 \mu \mathrm{mol} \mathrm{dm}{ }^{-3}$, com sensibilidade de $0,56( \pm 0,02) \mu \mathrm{A} \mathrm{dm}^{3} \mathrm{~mol}^{-1} \mathrm{~cm}^{-2}$, foi obtida. O limite de detecção foi $1,1 \mu \mathrm{mol} \mathrm{dm} \mathrm{dm}^{-3}$ e o tempo de resposta foi de $2 \mathrm{~s}$. O sensor apresentou resposta estável durante 40 determinações sucessivas. A repetibilidade avaliada em termos de desvio padrão relativo foi de 3,6\% para $\mathrm{n}=5$ e [catecol] $=$ $10 \mu \mathrm{mol} \mathrm{dm}{ }^{-3}$. As respostas do sensor para outros compostos fenólicos também foram investigadas em detalhes. Finalmente, a aplicabilidade do sensor foi testada em medicamento contendo dopamina e os resultados comparados favoravelmente com os obtidos com o método oficial.
\end{abstract}

The construction of an amperometric sensor for phenolic compounds using a carbon paste electrode modified with manganese phthalocyanine and histidine is reported. Under optimized conditions, at $0 \mathrm{mV}$ vs $\mathrm{Ag} / \mathrm{AgCl}$ in $0.1 \mathrm{~mol} \mathrm{dm}^{-3}$ phosphate buffer solutions ( $\mathrm{pH} 7.0$ ) containing $250 \mu \mathrm{mol} \mathrm{dm}{ }^{-3} \mathrm{H}_{2} \mathrm{O}_{2}$, a linear response for catechol from 20 up to $130 \mu \mathrm{mol} \mathrm{dm}{ }^{-3}$ was obtained with

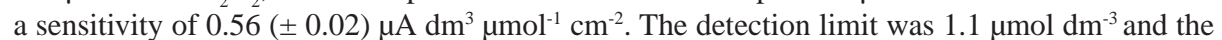
response time was $2 \mathrm{~s}$. The sensor presented stable response during 40 successive determinations. The repeatability, evaluated in terms of relative standard deviation, was $3.6 \%$ for $\mathrm{n}=5$ and [catechol] $=$ $10 \mu \mathrm{mol} \mathrm{dm}{ }^{-3}$. The sensor responses for other phenolic compounds were also investigated in details. Finally, the applicability of the sensor was tested in a pharmaceutical containing dopamine and the results compared favorably with those obtained with the official method.

Keywords: manganese phthalocyanine, phenolic compound, amperometric sensor

\section{Introduction}

Nowadays, the search for a more efficient electron transfer between the active site of the enzyme and the electrode surface has increased as a result of the high interest in more sensitive amperometric biosensors. One successful alternative that makes the electron transfer easier is the use of biomimetic chemistry and artificial enzymes, ${ }^{1-9}$ which try to mimic natural enzymes with

*e-mail: tanaka@ufma.br the same effectiveness and selectivity. This principle has been used to construct amperometric sensors with higher sensitivities and stabilities. ${ }^{10-13}$ In these biomimetic sensors, a simple redox substance is immobilized on the electrode surface to act as the active center of an enzyme and catalyze the substrate reaction in the same way. This concept has been investigated in our laboratories ${ }^{14-17}$ and remains an interesting field to be exploited. In this context, the structural similarity of metallophthalocyanines and metalloporphyrins with the prosthetic groups of the heme enzymes has led to the development of synthetic models 
capable of mimicking enzymatic reactions. Many systems have been reported for reactions involving cytochrome P-450 monooxygenases ${ }^{5,18-30}$ and peroxidases..$^{31-37}$

Although the heme enzymes contain iron atoms as the prosthetic groups, much effort has been devoted to investigate other metallic centers, such as cobalt, nickel and manganese. Kobayashi et al. ${ }^{38}$ reported the reduction of hydrogen peroxide by cobalt phthalocyanine $(\mathrm{CoPc})$ adsorbed on a highly oriented pyrolytic graphite electrode and suggested that $\mathrm{CoPc}$ mimics the prosthetic group of the peroxidase. On the other hand, manganese complexes have been extensively studied as a model for cytochrome P-450 monooxygenases, ${ }^{39-43}$ leading to the synthesis of a wide range of biomimetic catalysts to explain the epoxidation of alkenes and hydroxylation of unactivated $\mathrm{C}-\mathrm{H}$ bonds using dioxygen or mono-oxygen donors, such as $\mathrm{OCl}^{-}$or $\mathrm{H}_{2} \mathrm{O}_{2}{ }^{31,44-46}$ Ilda et al. ${ }^{45}$ reported the ring hydroxylations of phenylalanine derivatives and toluene by $\mathrm{H}_{2} \mathrm{O}_{2}$ catalyzed by manganese halogenated porphyrins in the presence of imidazole. Penta-coordinated manganese complexes, with the manganese surrounded by a peroxidase-like coordination sphere and an axial nitrogen atom donor, have been satisfactorily used as a biomimetic catalyst for asymmetric epoxidation of olefins with $\mathrm{H}_{2} \mathrm{O}_{2}{ }^{46}$

In this context, metallophthalocyanines (MPc) are structurally simpler, easier to synthesize and commercially available, when compared to enzymes. In addition, it is well known that MPc possess high thermal stability, many of them with melting points higher than $550{ }^{\circ} \mathrm{C},{ }^{47}$ and very low solubility. ${ }^{5}$ Furthermore, the central metal ion in these macrocycles can coordinate species in the axial positions, ${ }^{48}$ allowing to improve or even to initiate important biological reactions due to the rich redox chemistry involved. ${ }^{49,50}$ All these advantages make MPc potential compounds for the development of electrochemical biomimetic sensors.

On this basis, this work reports the use of manganese phtalocyanine immobilized in carbon paste to construct a sensor for the determination of phenolic compounds. In order to increase the rate of $\mathrm{H}_{2} \mathrm{O}_{2}$ decomposition and to obtain a sensor with high sensitivity and efficiency, ${ }^{46,51}$ histidine and imidazole were also tested in the electrode preparations.

\section{Experimental}

\section{Reagents and solutions}

All chemicals were of analytical grade. Phenol, hydrogen peroxide $(30 \%, \mathrm{~m} / \mathrm{v})$, monopotassium phosphate $\left(\mathrm{KH}_{2} \mathrm{PO}_{4}\right)$, sodium hydroxide, hydrochloric acid, citric acid, sodium chloride, sodium bisulfite, monosodium phosphate
$\left(\mathrm{NaH}_{2} \mathrm{PO}_{4}\right)$, disodium phosphate $\left(\mathrm{Na}_{2} \mathrm{HPO}_{4}\right)$ and acetyl salicylic acid were acquired from Synth, São Paulo-Brazil. Graphite powder (99.9\%), mineral oil, catechol, uric acid, 3-nitrophenol, $( \pm)$ norepinephrine L-bitartrate hydrate, 4-aminosalicylic acid and manganese phthalocyanine were purchased from Aldrich, Milwaukee-USA. Ascorbic acid, $o$-phenylenediamine, 2-aminophenol, 3-aminophenol, 2-nitrophenol, hydroquinone, imidazole, resorcinol and sodium salicylate were from Merck, DarmstadtGermany. Dopamine (3,4-dihydroxyphenethylamine), serotonin (5-hydroxytryptamine), L-dopa (3,4dihydroxyphenylalanine) and D,L-histidine were acquired from Sigma, St. Louis-USA. 4-Aminophenol, 4-nitrophenol and $p$-phenylenediamine dihydrochloride were purchased from Riedel-De Haën, Germany. Acetaminophen was supplied by Acros, New Jersey-USA. Buffer and phenolic compound solutions were prepared using water purified in a Milli-Q Millipore system. The actual $\mathrm{pH}$ of the buffer was determined with a 350 Corning $\mathrm{pH} / \mathrm{Ion}$ analyzer.

\section{Construction of the sensor}

In order to obtain homogeneous modified carbon pastes, $100 \mathrm{mg}$ of graphite powder were mixed with $15 \mathrm{mg}$ of $\mathrm{MnPc}, 1.0 \mathrm{~cm}^{3}$ of $0.1 \mathrm{~mol} \mathrm{dm}^{-3}$ phosphate ( $\mathrm{pH} 7.0$ ) buffer solution and adequate amounts of histidine (His), to get MnPc:His mass ratios of 1:2 (30 mg His); 1:4 (60 mg His) and 1:6 (90 mg His). After drying at room temperature, a paste was obtained by adding $100 \mathrm{~mm}^{3}$ of mineral oil. This paste was put into a cavity at the extremity of a glass tube, containing a Pt slide (geometrical area of $0.07 \mathrm{~cm}^{2}$ ) for electrical contact. Alternatively, imidazole (Im) was also tested with a 1:6, MnPc:Im mass ratio.

\section{Electrochemical measurements}

The electrochemical measurements were carried out with an Autolab Echo Chemie potentiostat model PGSTAT10 and using a conventional three electrode electrochemical cell with the carbon paste electrode as the working electrode, and a saturated $\mathrm{Ag} / \mathrm{AgCl}$ electrode and a Pt wire as reference and auxiliary electrodes, respectively.

The amperometric measurements were initiated with the electrochemical cell containing $5.00 \mathrm{~cm}^{3}$ of the buffer solution and applying an adequate potential until current stabilization. Then, hydrogen peroxide solution was added and the current monitored to obtain steady state conditions. After $30 \mathrm{sec}$ intervals, suitable aliquot of a standard phenolic solution were added to obtain the amperograms. 


\section{Results and Discussion}

\section{Paste composition and electrode response}

In order to obtain sensors with high sensitivity, molecules with single nitrogen-donor ligand were tested for the paste preparation, based on the following reasons: (i) it has been demonstrated that addition of imidazole to manganese-containing catalysts is crucial to increase $\mathrm{H}_{2} \mathrm{O}_{2}$ decomposition; ${ }^{46,51}$ (ii) it is known that histidine is an aminoacid commonly found in the redox sites of several enzymes; ${ }^{52-54}$ and (iii) histidine has been used in the construction of mimetic systems to prepare sensors with success. ${ }^{15,16}$

Initially, the effect of imidazole (Im) addition on the sensor response was investigated by preparing modified carbon paste electrodes with manganese phthalocyanine $(\mathrm{MnPc})$ immobilized together with $\mathrm{Im}$, in a mass ratio of 1:6. However, when in contact with the buffer solution, the modified carbon paste leached out quickly from the electrode cavity. This behavior could be explained by interactions of the acid graphite- $\mathrm{COOH}$ and phenolic graphite-OH groups on the graphite surface with Im, which are soluble in aqueous media. Based on these results, imidazole was substituted by histidine (His) as an alternative.

The presence of His in the modified carbon paste was shown to be essential for catalysis, as shown in Figure 1, which compares the responses for cathecol with an unmodified carbon paste electrode and with electrodes modified with $\mathrm{MnPc}$ and with $\mathrm{MnPc} / \mathrm{His}$. No responses for successive additions of catechol (or other phenolic compounds) were observed on sensors prepared with carbon paste without His (curves a and b). On the other hand, good responses were obtained with sensors constructed with carbon pastes modified with $\mathrm{MnPc} / \mathrm{His}$ (curve $\mathrm{c}$ of Figure 1).

The influence of the MnPc:His mass ratio on the sensor response was investigated by preparing pastes with $1: 2$, 1:4 and 1:6 mass ratios. The results listed in Table 1 show the signals obtained for $30 \mu \mathrm{mol} \mathrm{dm}{ }^{-3}$ catechol in solutions containing $240 \mu \mathrm{mol} \mathrm{dm}{ }^{-3} \mathrm{H}_{2} \mathrm{O}_{2}$. A higher response can be observed for the paste with a 1:6 mass ratio, however, in the tested range of MnPc:His, practically the same responses were obtained. This behavior suggests that the MnPc:His mass ratio does not strongly affect the analyte-catalyst (Mn complex) interaction. This aspect is important to assure the same response in a wide range of $\mathrm{MnPc}$ :His mass ratios (1:2-1:6), giving high reproducibility in sensor preparation. Furthermore, it is important to point out that when MnPc:His mass ratios higher than 1:6 were used paste

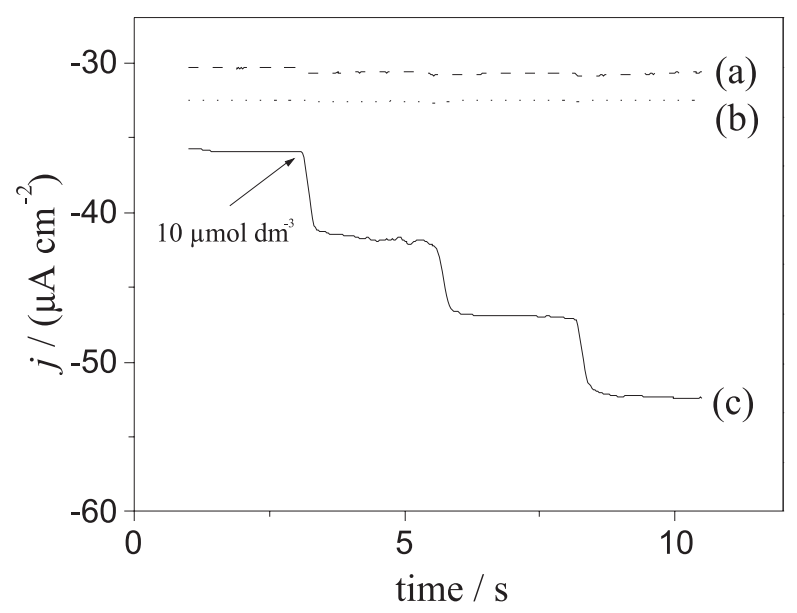

Figure 1. Profile response of sensors constructed using carbon paste: unmodified (a), modified with $\mathrm{MnPc}$ (b) and $\mathrm{MnPc} / \mathrm{His}$ (c). In the figure each 'step' corresponds to an increment of $10 \mu \mathrm{mol} \mathrm{dm}{ }^{-3}$ of catechol into the working solution. Applied potential of $0 \mathrm{mV}$ vs $\mathrm{Ag} / \mathrm{AgCl}$, in $0.1 \mathrm{~mol} \mathrm{dm}^{-3}$ phosphate buffer ( $\mathrm{pH} 7.0$ ) containing $250 \mu \mathrm{mol} \mathrm{dm} \mathrm{H}_{2} \mathrm{O}_{2}$.

homogeneity was prejudiced and consequently the stability and repeatability of the measurements.

Table 1. MnPc:His mass ratio influence on the sensor response $\left(\mu \mathrm{A} \mathrm{cm}^{-2}\right)$. Measurements carried out in $0.1 \mathrm{~mol} \mathrm{dm}^{-3}$ phosphate buffer solution (pH 7.0) containing $240 \mu \mathrm{mol} \mathrm{dm} \mathrm{dm}_{2} \mathrm{H}_{2}$ and $30 \mu \mathrm{mol} \mathrm{dm} \mathrm{dm}^{-3}$ catechol. Applied potential $0 \mathrm{mV}$ vs $\mathrm{Ag} / \mathrm{AgCl}$

\begin{tabular}{lccc}
\hline Mass ratio $\mathrm{MnPc}:$ His & $1: 2$ & $1: 4$ & $1: 6$ \\
\hline$\Delta j /\left(\mu \mathrm{A} \mathrm{cm} \mathrm{cm}^{-2}\right)$ & 15 & 16 & 18 \\
\hline
\end{tabular}

\section{Hydrogen peroxide influence}

Figure 2 shows the results obtained in the experiments carried out in the presence and the absence of hydrogen peroxide. In the absence of $\mathrm{H}_{2} \mathrm{O}_{2}$ (curve $a$ ), very small cathodic currents were observed, which could be attributed to the incapability of the modified carbon paste electrode to directly reduce phenolic species. On the other hand, good responses for peroxide (data not shown) and catechol (curve b in Figure 2) in presence of $\mathrm{H}_{2} \mathrm{O}_{2}$ were observed, demonstrating that peroxide plays an important role in the catalytic process.

A higher sensitivity was obtained for $\mathrm{H}_{2} \mathrm{O}_{2}$ concentration of $500 \mu \mathrm{mol} \mathrm{dm}{ }^{-3}$, however such high concentrations resulted in poor stability of the electrode. Therefore, the use of a minimum amount of hydrogen peroxide in the measurements is desirable, but it should present good sensitivity. Thus, $250 \mu \mathrm{mol} \mathrm{dm} \mathrm{d}^{-3}$ hydrogen peroxide allows good sensitivity and avoids the reduction of electrode stability. This concentration was established for further experiments.

Based on these results, a possible mechanism for the sensor response was proposed as schematized in Figure 3. This 


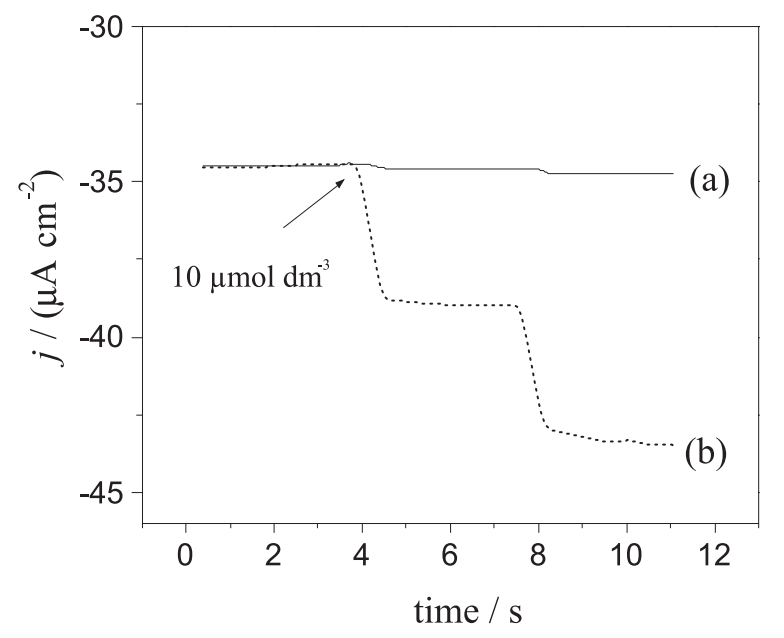

Figure 2. Signals obtained with the proposed sensor based on carbon paste modified with $\mathrm{MnPc} / \mathrm{His}$, in absence (a) and presence (b) of $250 \mu \mathrm{mol} \mathrm{dm}^{-3}$ $\mathrm{H}_{2} \mathrm{O}_{2}$. Each 'step' corresponds to an increment of $10 \mu \mathrm{mol} \mathrm{dm}{ }^{-3}$ catechol. Applied potential of $0 \mathrm{mV} v s \mathrm{Ag} / \mathrm{AgCl}$ in $0.1 \mathrm{~mol} \mathrm{dm}^{3}$ phosphate buffer ( $\mathrm{pH} 7.0)$.

mechanism is similar to those proposed for determinations of phenolic compounds with biomimetic catalysts of dopamine $\beta$-monooxigenase, peroxidase and tyrosinase enzymes, ${ }^{15-17}$ where the most important stage for phenolic quantification is the electrochemical reduction of quinone species on the electrode surface, recycling the substrate, and consequently resulting in signal amplification and reduction of the detection potential of the phenolic compound.

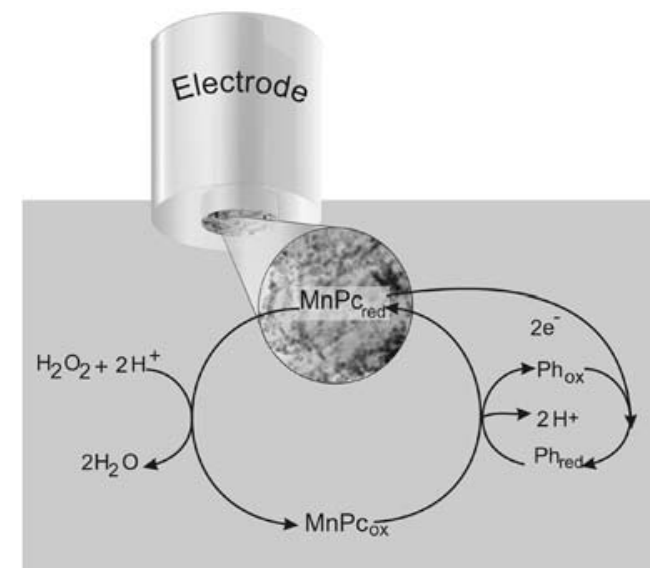

Figure 3. Proposed mechanism for phenolic compound oxidation for the sensor modified with MnPc. Manganese phtalocyanine is represented by $\mathrm{MnPc}_{\text {red }}, \mathrm{MnPc}_{\text {ox }}$ is oxidized $\mathrm{MnPc}$, and $\mathrm{Ph}_{\text {red }}$ and $\mathrm{Ph}_{\text {oxy }}$ are the reduced and oxidized phenol species, respectively.

\section{Measurement conditions}

In order to evaluate the influence of anaerobic or aerobic conditions during the amperometric measurements, experiments in the absence of oxygen ( $\mathrm{N}_{2}$ saturated solution), in air-saturated solutions (bubbling air) and in air-equilibrated solutions (without bubbling any gas) were performed. In airsaturated solutions, the sensitivities were lower than those obtained in the air-equilibrated or anaerobic conditions (data not shown). A possible explanation for this observation is based on the fact that in the air-saturated condition the possibility exists of $\mathrm{Mn}(\mathrm{III})$ oxidation towards other higher oxidation states (IV or V), decreasing the amount of effective redox centers for reaction with $\mathrm{H}_{2} \mathrm{O}_{2}$. By considering that under anaerobic conditions a slightly better electrode response was observed and, taking into account cost and time consumption, for analytical purposes, the measurements were carried out in air-equilibrated solutions.

\section{Influences of the applied potential, buffer and $\mathrm{pH}$ solutions}

In order to establish the optimized conditions for amperometric measurements, the influence of the applied potential, buffer solution and $\mathrm{pH}$ were also investigated and the best sensor responses were obtained at $0 \mathrm{mV} v s \mathrm{Ag} / \mathrm{AgCl}$ (Figure 4) in monopotassium phosphate buffer solution (Table 2) and $\mathrm{pH}$ 7.0. It can be seen that the current density referring to catechol reduction decreases from $0 \mathrm{mV}$ up to $-100 \mathrm{mV} v \mathrm{Ag} / \mathrm{AgCl}$. This behavior becomes associated with a competitive mechanism for manganese electroreduction (at about $-10 \mathrm{mV}$ versus $\mathrm{Ag} / \mathrm{AgCl}$ ) which can result in a low number of active sites of oxidized manganese species $\left(\mathrm{MnPc}_{\mathrm{ox}}\right)$ promoting a decrease in the efficiency of phenol oxidation by the chemical route (as depicted in Figure 3). Thus, the use of more negative potentials than that necessary for manganese site reduction results in a decrease in the number of active sites and, as a consequence, promotes a decrease of the electrical current for phenol reduction due to the lesser efficiency of the chemical step.

In the study carried out to determine the best monopotassium phosphate buffer concentration, the results showed that in the concentration range from 0.05 up to $0.25 \mathrm{~mol} \mathrm{dm}^{-3}$ practically the same responses were obtained (Table 3). Thus, $0.10 \mathrm{~mol} \mathrm{dm}^{-3}$ phosphate buffer was selected for further experiments.

\section{Sensor characteristics}

Under optimized conditions, the proposed sensor showed a linear response range for catechol concentration, variyng from 20 up to $130 \mu \mathrm{mol} \mathrm{dm}{ }^{-3}$ (Figure 5), and expressed by the equation:

$\Delta j / \mu \mathrm{Acm}^{-2}=3.3( \pm 1.9)+0.56( \pm 0.02)[$ Catechol $] / \mu \mathrm{mol} \mathrm{dm}{ }^{-3}$

with a correlation coefficient of 0.996 for $\mathrm{n}=7$. 


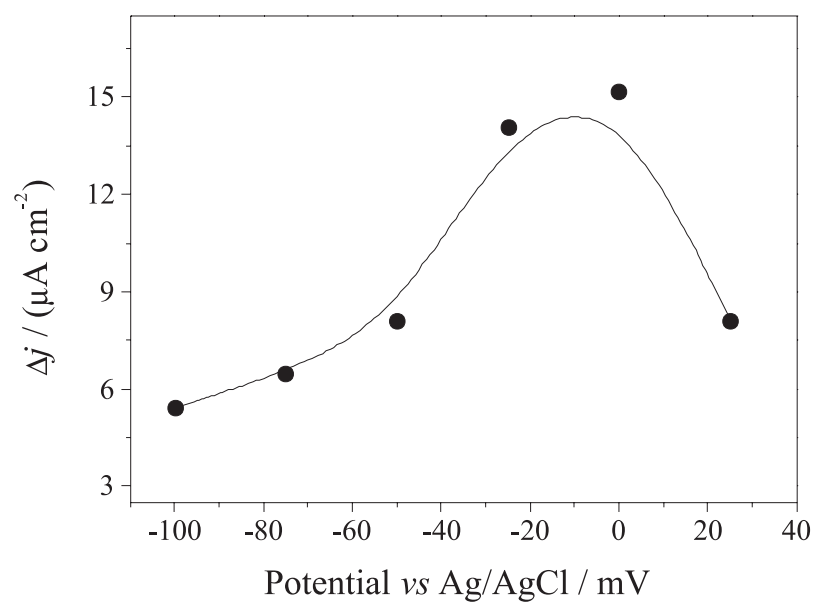

Figure 4. Influence of the applied potential on the sensor response. Measurements carried out in $0.1 \mathrm{~mol} \mathrm{dm}^{-3}$ phosphate buffer ( $\mathrm{pH} 7.0$ ), containing $30 \mu \mathrm{mol} \mathrm{dm}{ }^{-3}$ of catechol and $250 \mu \mathrm{mol} \mathrm{dm}{ }^{-3} \mathrm{of}_{2} \mathrm{O}_{2}$.

Table 2. Influence of the buffer on the sensor response $\left(\mu \mathrm{A} \mathrm{cm}{ }^{-2}\right)$ for catechol. Measurements carried out in $0.1 \mathrm{~mol} \mathrm{dm}^{-3}$ buffer ( $\mathrm{pH}$ 7.0) in the presence of $240 \mu \mathrm{mol} \mathrm{dm}^{-3} \mathrm{H}_{2} \mathrm{O}_{2}$ and $30 \mu \mathrm{mol} \mathrm{dm}^{-3}$ catechol. Applied potential $0 \mathrm{mV}$ vs $\mathrm{Ag} / \mathrm{AgCl}$

\begin{tabular}{lccc}
\hline Buffer & $\mathrm{KH}_{2} \mathrm{PO}_{4} / \mathrm{NaOH}$ & Mcllvaine & Sörensen \\
\hline$\Delta j /\left(\mu \mathrm{A} \mathrm{cm}^{-2}\right)$ & 15 & 13 & 11 \\
\hline
\end{tabular}

Table 3. Influence of the $\mathrm{KH}_{2} \mathrm{PO}_{4}$ concentration in the phosphate buffer on the sensor response. Measurements carried out in buffer solution $(\mathrm{pH}$ 7.0) containing $240 \mu \mathrm{mol} \mathrm{dm}{ }^{-3} \mathrm{H}_{2} \mathrm{O}_{2}$ and $30 \mu \mathrm{mol} \mathrm{dm}{ }^{-3}$ catechol, applied potential of $0 \mathrm{mV}$ vs $\mathrm{Ag} / \mathrm{AgCl}$

\begin{tabular}{lccccc}
\hline$[$ Buffer $] /\left(\mathrm{mol} \mathrm{dm}^{-3}\right)$ & 0.025 & 0.05 & 0.10 & 0.25 & 0.50 \\
\hline$\left.\Delta j /(\mu \mathrm{A} \mathrm{cm})^{-2}\right)$ & 12 & 15 & 15 & 14 & 12 \\
\hline
\end{tabular}

A detection limit of $1.1 \mu \mathrm{mol} \mathrm{dm}^{-3}$ was determined using a signal to noise ratio of 3 . In addition, considering the time to reach $100 \%$ of the signal, the response time was about $2 \mathrm{~s}$, which is better than the response times

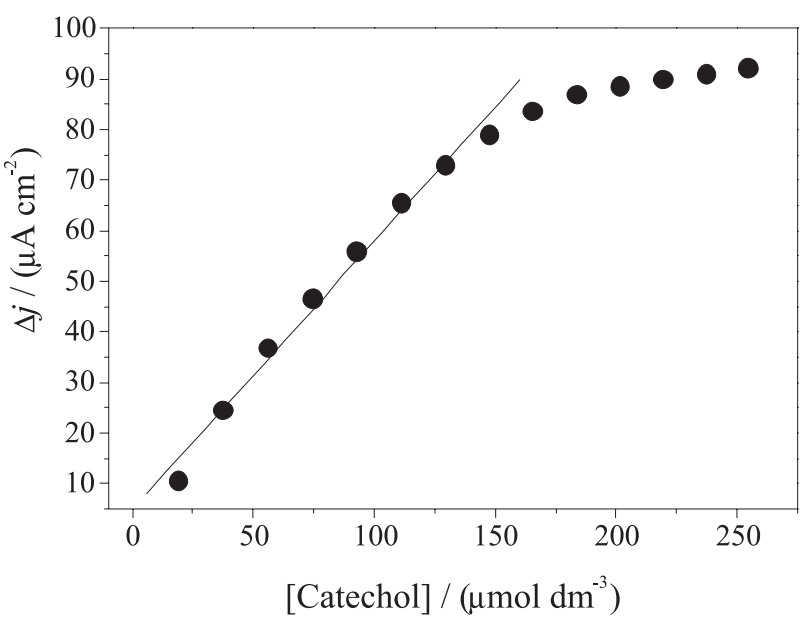

Figure 5. A typical profile of the sensor response using the optimized conditions. Applied potential of $0 \mathrm{mV}$ vs $\mathrm{Ag} / \mathrm{AgCl}$, in $0.1 \mathrm{~mol} \mathrm{dm}^{-3}$ phosphate buffer solution ( $\mathrm{pH} 7.0$ ), containing $250 \mu \mathrm{mol} \mathrm{dm} \mathrm{dm}^{-3}$ of $\mathrm{H}_{2} \mathrm{O}_{2}$.

of other sensors presented in the literature for phenolic compounds. ${ }^{55,56}$

The repeatability in the measurements, expressed as the relative standard deviation (r.s.d), was evaluated by recording the signals through five successive experiments in $10 \mu \mathrm{mol} \mathrm{dm}{ }^{-3}$ catechol solutions and resulted in a value of $3.6 \%$. Under optimized operational conditions, the sensor presented a $6 \%$ decrease in the sensitivity after the first ten measurements and presented good stability for 40 successive determinations with a r.s.d. of $6.4 \%$.

A comparison of the analytical parameters for catechol with those previously reported for other biomimetic systems, ${ }^{15-17}$ under similar experimental conditions, is presented in Table 4. A good detection limit and a higher sensitivity are observed, even when compared to biosensors based on peroxidase or tyrosinase enzymes ${ }^{55-58}$ for phenol determinations. Such good analytical responses can be attributed to the efficiency of the electron transfer between the peroxide and $\mathrm{MnPc} / \mathrm{His}$ (biomimetic catalyst) and also phenolic compound and $\mathrm{MnPc} / \mathrm{His}$.

Table 4. Analytical parameters for cathecol detection with biomimetic sensors under optimized amperometric conditions

\begin{tabular}{|c|c|c|c|c|c|}
\hline Biomimetic Sensor & Electrolyte & $\begin{array}{c}\text { Dynamic Range / } \\
\left(\mu \mathrm{mol} \mathrm{dm}^{-3}\right)\end{array}$ & $\begin{array}{l}\text { Detection Limit / } \\
\left(\mu \mathrm{mol} \mathrm{dm}^{-3}\right)\end{array}$ & $\begin{array}{c}\text { Sensitivity / } \\
\left(\mu \mathrm{A} \mathrm{dm}{ }^{-3} \mu \mathrm{mol}^{-1} \mathrm{~cm}^{-2}\right)\end{array}$ & Ref. \\
\hline MnPc-His & $\begin{array}{c}0.1 \mathrm{~mol} \mathrm{dm}^{-3} \\
\text { phosphate (pH 7.0) }\end{array}$ & $20-130$ & 1.1 & 0.56 & This work \\
\hline $\mathrm{CuPc}-\mathrm{His}$ & $\begin{array}{c}0.25 \mathrm{~mol} \mathrm{dm}^{-3} \\
\text { phosphate (pH 6.9) }\end{array}$ & $40-250$ & 9.0 & 0.0046 & 15 \\
\hline FeT4MPyP-His & $\begin{array}{c}0.25 \mathrm{~mol} \mathrm{dm}^{-3} \\
\text { succinate }(\mathrm{pH} \mathrm{4.0)}\end{array}$ & $0.6-6.0$ & 0.35 & 0.061 & 16 \\
\hline$\left[\mathrm{Cu}(\text { bipy })_{2}\right] \mathrm{Cl}_{2}$ & $\begin{array}{c}0.25 \mathrm{~mol} \mathrm{dm}^{-3} \\
\text { phosphate (pH 7.0) }\end{array}$ & $100-250$ & 8.0 & 0.0082 & 17 \\
\hline
\end{tabular}

MnPc: manganese phthalocyanine; CuPc: copper phthalocyanine; $\left[\mathrm{Cu}(\text { bipy })_{2}\right] \mathrm{Cl}_{2}:$ bis(2,2'-bipyridil) copper chloride; FeT4MpyP: iron Tetra-( $N$-methyl-4-pyridyl)porphyrin; His: histidine. 


\section{Effect of the phenolic substrates}

In order to investigate the sensor response for other substrates, with the aim to find applicability for the proposed sensor, a detailed study was carried out with twenty different phenolic compounds, including monophenolic compounds, aromatic amines and nitro-phenols. The results are summarized in Figure 6 for ten compounds, with the order of sensitivity decreasing in the following sequence: 4 -aminophenol $>$ hydroquinone $>p$-phenylenediamine $>$ 2-aminophenol $>o$-phenylenediamine $>$ catechol $>$ dopamine > acetaminophen > norepinephrine > L-dopa. No response was observed for the other ten phenols evaluated: phenol, serotonin, resorcinol, 2-, 3- and 4-nitrophenol, imidazol, 4-aminosalicylic acid, acetyl salicylyc acid and sodium salicylate. These results indicate that the substituent group in the phenolic compounds influences the sensor response. Compounds with electron withdrawing groups, such as nitro-phenol, were not detected by the proposed sensor. It should be noted that higher signals were obtained for compounds with electron donor substituents in the ortho and para positions. Finally, once it was verified that the sensor presented a good sensitivity for dopamine, the determination of this important analyte in real samples was tested.

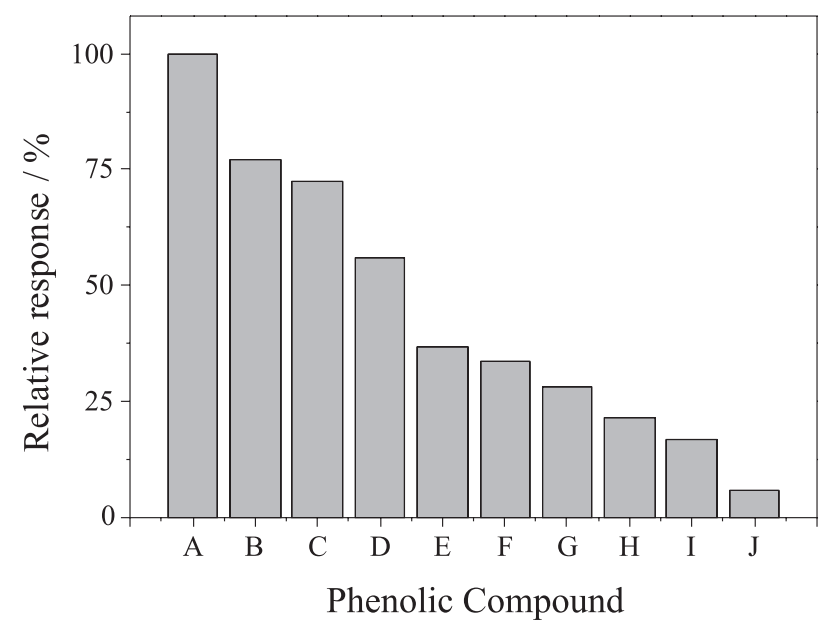

Figure 6. Relative response (\%) obtained for different substrates at an applied potential of $0 \mathrm{mV}$ vs $\mathrm{Ag} / \mathrm{AgCl},\left[\mathrm{H}_{2} \mathrm{O}_{2}\right]=250 \mu \mathrm{mol} \mathrm{dm}{ }^{-3}$ and [phenolic compounds] $=30 \mu \mathrm{mol} \mathrm{dm}^{-3}$. A-J: 4-aminophenol, hydroquinone, $p$-phenylenediamine, 2-aminophenol, $o$-phenylenediamine, catechol, dopamine, acetaminophen, norepinephrine, L-dopa, respectively.

Sensor application: interferents, recovery and analysis of pharmaceutical formulations

In order to evaluate the sensor applicability, pharmaceutical samples of dopamine injections were used. Firstly the sensor response was tested in the presence of $20 \mu \mathrm{mol} \mathrm{dm} \mathrm{dm}^{-3}$ dopamine and compounds such as ascorbic acid, uric acid, acetyl salicilyc acid and sodium salicylate, and other compounds commonly contained in the pharmaceutical formulations, such as sodium chloride and sodium bisulfite, in different molar ratios. The results obtained showed that practically no interference of uric acid, acetyl salicilyc acid and sodium salicylate is observed in molar ratio (interferent/analyte) between 0.5 to 4 . Ascorbic acid gave a negative interference ( $80 \%$ in equal molar ratio with dopamine) presumably due to the reaction with hydrogen peroxide, thus this is a serious interferent for direct analysis. To overcome this problem many different strategies have been proposed, such as: the use of a nafion membrane, that repels ascorbic acid and other negatively charged species, ${ }^{59}$ the use of the multivariate calibration methods ${ }^{60}$ the addition of ethylenediaminetetraacetate in the supporting electrolyte ${ }^{61,62}$ or addition of ascorbate oxidase enzyme. ${ }^{63} \mathrm{An}$ interference of $62 \%$ for molar ratios higher than 150 was observed for sodium bisulfite.

The matrix effect of dopamine samples was evaluated carrying out a recovery study, obtaining an average recovery of $103 \pm 4 \%$ for a solution of $20 \mu \mathrm{mol} \mathrm{dm}{ }^{-3}$ dopamine. In the dopamine determinations carried out with the proposed sensor, the results (Table 5) compared favorably to those obtained with the USP official method, ${ }^{64}$ based on UV spectrophotometry measurements at $281 \mathrm{~nm}$, suggesting that the results are statistically the same with $95 \%$ of confidence level.

Table 5. Determination of dopamine in pharmaceutical preparations

\begin{tabular}{ccc}
\hline \multicolumn{3}{c}{ Dopamine contained in $10.0 \mathrm{~mL}$ of sample $/ \mathrm{mg}$} \\
\hline nominal value & USP & Sensor \\
\hline 50 & $53 \pm 2^{\mathrm{a}}$ & $55 \pm 2^{\mathrm{a}}$ \\
\hline
\end{tabular}

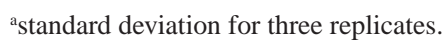

\section{Conclusions}

This work clearly shows that using a compound as simple as MnPc in the construction of a sensor for sensitive detection of catechol, dopamine and analogous compounds is possible. This sensor showed a wider linear response range and higher stability and repeatability, compared to those described in the literature (biomimetic or enzymatic). Indeed, this sensor was successfully employed in dopamine determination in pharmaceutical formulations.

\section{Acknowledgments}

The authors gratefully acknowledge the Conselho Nacional de Desenvolvimento Científico e Tecnológico 
(CNPq), the Fundação de Amparo à Pesquisa do Estado de São Paulo (FAPESP) and the Coordenação de Aperfeiçoamento de Pessoal de Nível Superior (CAPES) for financial support and fellowships.

\section{References}

1. Zagal, J.; Bedioui, F.; Dodelet, J. P.; $N_{4}$-Macrocyclic Metal Complex, Springer: Heidelberg, 2006.

2. Sotomayor, M. D. P. T.; Tanaka, A. A.; Freire, R. S.; Kubota, L. T. In Encyclopedia of Sensors; Grimes, C. A.; Dickey, E. C.; Pishko, M. V., eds., American Scientific Publishers: Stevenson Ranch, 2006, pp. 195-210.

3. Breslow, R.; Artificial Enzymes, Wiley: Indianapolis, 2005.

4. Hubin, T. J.; Coord. Chem. Rev. 2003, 241, 27.

5. Motherwell,W. B.; Bingham, M. J.; Six, Y.; Tetrahedron 2001, $57,4663$.

6. Costamagna, J.; Ferraudi, G.; Matsuhiro, B.; Campos-Vallette, M.; Canales, J.; Villagrán, M.; Vargas, J.; Aguirre, M. J.; Coord. Chem. Rev. 2000, 196, 125.

7. Breslow, R.; Acc. Chem. Res. 1995, $28,146$.

8. Wiseman, A.; Dalton, H.; Trends Biotechnol. 1987, 5, 241.

9. Breslow, R.; Acc. Chem. Res. 1980, 13, 170.

10. Berchmans, S.; Gomathi, H.; Rao, G. P.; Sens. Actuators, B 1998, 50, 156.

11. Zen, J. M.; Lai,Y.Y.; Ilangovan, G.; Kumar, A. S.; Electroanalysis 2000, 12, 280.

12. Hasebe, Y.; Akiyama, T.; Yagisawa, T.; Uchiyama, S.; Talanta 1998, 47, 1139.

13. Karyakin, A. A.; Karyakina, E. E.; Sens. Actuators, B 1999, 57, 268.

14. Sotomayor, M. D. P. T.; Sigoli, A.; Lanza, M. R. V.; Tanaka, A. A.; Kubota, L. T.; J. Braz. Chem. Soc. 2008, 19, 734.

15. Sotomayor, M. D. P. T.; Tanaka, A. A.; Kubota, L. T.; Anal. Chim. Acta 2002, 455, 215.

16. Damos, F. S.; Sotomayor, M. D. P. T.; Kubota, L. T.; Tanaka, S. M. C. N.; Tanaka, A. A.; Analyst 2003, 128, 255.

17. Sotomayor, M. D. P. T.; Tanaka, A. A.; Kubota, L. T.; Electroanalysis 2003, 15, 787.

18. Nam, W.; Lee, H. J.; Oh, S. Y.; Kim, C.; Jang, H. G.; J. Inorg. Biochem. 2000, 80, 219.

19. Hlavica, P.; Eur. J. Biochem. 2004, 271, 4335.

20. Hlavica, P.; Curr. Drug Metab. 2007, 8, 594.

21. Chauhan, S. M. S.; Kumari, P.; Tetrahedron Lett. 2007, 48, 5035.

22. Jung, C.; Drug Metab. Rev. 2007, 39, 501.

23. Davydov, R.; Razeghifard, R.; Im, S.-C.; Waskell, L.; Hoffman, B. M.; Biochemistry 2008, 47, 9661.

24. Hirao, H.; Kumar, D.; Shaik, S.; J. Inorg. Biochem. 2006, 100, 2054.

25. Newcomb, M.; Chandrasena, R. E. P.; Biochem. Biophys. Res. Commun. 2005, 338, 394.
26. Iyanagi, T.; Biochem. Biophys. Res. Commun. 2005, 338, 520.

27. Faria, A. L.; Mac, L. T. C. O.; Assis, M. D.; Catal. Today 2008, 133,863 .

28. Kiseleva, E. N.; Lomova, T. N.; Klyueva, M. E.; Russ. J. Gen. Chem. 2007, 77, 641.

29. Nam, W.; Kim, I.; Lim, M. H.; Choi, H. J.; Lee, J. S.; Jang, H. G.; Chem. Eur. J. 2002, 8, 2067.

30. Barkanova, S. V.; Makarova, E. A.; J. Mol. Catal. A: Chem. 2001, 174, 89.

31. Chauhan, S. M. S.; Kalra, B.; Mohapatra, P. P.; J. Mol. Catal. A: Chem. 1999, 137, 85.

32. Kamp, N. W. J.; Lindsay Smith, J. R.; J. Mol. Catal. A: Chem. 1996, 113, 131.

33. Bell, S. E. J.; Cooke, P. R.; Inchley, P.; Leanord, D. R.; Lindsay Smith J. R.; Robbins, A.; J. Chem. Soc., Perkin Trans. 1991, 2 , 549.

34. Colclough, N.; Lindsay Smith, J. R.; J. Chem. Soc., Perkin Trans. 1994, 2, 1139.

35. Shun, Z.; Tachikawa, H.; Anal. Chem. 1992, 64, 112.

36. Kang, T. F.; Shen, G. L.; Yu, R. Q.; Anal. Lett. 1997, 30, 647.

37. Degrand, C.; Limoges, B.; Martre, A. M.; Schollhorn, B.; Analyst 2001, 126, 887.

38. Kobayashi, N.; Janda, P.; Lever, A. B. P.; Inorg. Chem. 1992 , 31,5172 .

39. Meunier, B.; Chem. Rev. 1992, 92, 1411.

40. Hill, C. L.; Schardt, B. C.; J. Am. Chem. Soc. 1980, 102, 6374.

41. Groves, J. T.; Kruper, W. J.; Haushalter, R. C.; J. Am. Chem. Soc. 1980, 102, 6375.

42. Guilmet, E.; Meunier, B.; Tetrahedron Lett. 1980, 21, 4449.

43. Collman, J. P.; Zhang, X.; Hembre, R. T.; Brauman, J. I.; J. Am. Chem. Soc. 1992, 112, 5325.

44. Lee, H. J.; Nam, W.; Oh, S. Y.; Kim, C.; Jang, H. G.; J. Inorg. Biochem. 2000, 80, 219.

45. Ilda, K.; Nango, M.; Okada, K.; Matsumoto, S.; Matsuura, M.; Yamashita, K.; Tsuda, K.; Kurono, Y.; Kimura, Y.; Chem. Lett. 1994, 7, 1307.

46. Berkessel, A.; Frauenkron, M.; Schwenkreis, T.; Steinmetz, A.; J. Mol. Catal. A: Chem. 1997, 117, 339.

47. Garcia-Sanchez, M. A.; Campero, A.; Polyhedron 2000, 19, 2383.

48. Iliev, V.; J. Mol. Catal. 1993, 85, L269.

49. Perez, E. F.; Kubota, L. T.; Tanaka, A. A.; Oliveira Neto, G.; Electrochim. Acta 1998, 43, 1665.

50. Komorsky-Lovric, S.; J. Electroanal. Chem. 1995, 397, 211.

51. Devereux, M.; Curran, M.; McCann, M.; Casey, M. T.; McKee, V.; Polyhedron 1995, 14, 2247.

52. Blackburn, N. J.; Hasnain, S. S.; Pettingill T. M.; Strange, R. W.; J. Biol. Chem. 1991, 266, 23120.

53. Poulos, T. L.; Adv. Inorg. Biochem. 1988, 7, 1. 
54. Sono, M.; Roach, M. P.; Coulter, E. D.; Dawson, J. H.; Chem. Rev. 1996, 96, 2841.

55. Rosatto, S. S.; Kubota, L. T.; Oliveira Neto, G.; Anal. Chim. Acta 1999, 390, 65.

56. Cosnier, S.; Fombon, J.-J.; Labbe, P.; Limosin, D.; Sens. Actuators, B 1999, 59, 134.

57. Lima, A. W. O.; Vidsiunas, E. K.; Nacimento, V. B.; Angnes, L.; Analyst 1998, 123, 2377.

58. Wang, B.; Dong, S.; J. Electroanal. Chem. 2000, 487, 45.

59. Zhou, D. M.; Ju, H. X.; Chen, H. Y.; J. Electroanal. Chem. 1996, 408, 219

60. Carvalho, R. M.; Oliveira, O. N.; Kubota, L. T.; Anal. Chim. Acta 2000, 420, 109.
61. Carvalho, R. M.; Kubota, L. T.; Rath, S.; J. Electroanal. Chem. 2003, 548, 19.

62. Winter, E.; Carvalho, R. M.; Kubota, L. T.; Rath, S.; J. Braz. Chem. Soc. 2003, 14, 564.

63. Copra, A.; MSc Dissertation, University of Sarajevo, Sarajevo, 2001.

64. United States Pharmacopeia National Formulary XXI, US Pharmacopeial Convention, Rockville, MD, 1985, p. 353.

Received: January 24, 2009

Web Release Date: June 26, 2009

FAPESP helped in meeting the publication costs of this article. 